\title{
Parametric In Vivo Imaging of Benzodiazepine Receptor Distribution in Human Brain
}

\author{
Kirk A. Frey, MD, PhD, ${ }^{\dagger} \dagger$ Vjera A. Holthoff, MD $\ddagger$ Robert A. Koeppe, PhD, ${ }^{*}$ Douglas M. Jewett, PhD, \\ Michael R. Kilbourn, $\mathrm{PhD},{ }^{*}$ and David E. Kuhl, MD*
}

\begin{abstract}
Emission computed tomographic methods for the in vivo quantification of radioligand-binding sites in human brain have previously been limited either by a lack of correction for possible effects of altered ligand transport or by highly complicated physiological models that preclude display of binding data in a detailed anatomical format. We investigated the application of a simplified compartmental model to the kinetic analysis of in vivo ligand binding to central benzodiazepine receptors. The human brain distribution of $\left[{ }^{11} \mathrm{C}\right]$ flumazenil, as determined by dynamic positron emission tomography, combined with metabolite-corrected arterial blood samples, permitted estimations of local cerebral ligand transport and of receptor binding. This approach allows calculation of transport and binding "maps" on a pixel-by-pixel basis, resulting in the display of binding data in a familiar tomographic format while maintaining much of the physiological accuracy inherent in more complex methods. The results obtained in a study of 6 normal volunteers revealed good interindividual precision, with coefficients of variation between 10 and $15 \%$ of mean regional values, suggesting the utility of this approach in future clinical studies of benzodiazepine receptor binding.
\end{abstract}

Frey KA, Holthoff VA, Koeppe RA, Jewett DM, Kilbourn MR, Kuhl DE. Parametric in vivo imaging of benzodiazepine receptor distribution in human brain. Ann Neurol 1991;30:663-672

The potential for noninvasive imaging of cerebral neurotransmitter receptors and drug-binding sites has been demonstrated repeatedly with the use of positron emission tomography (PET) and with the related technique, single-photon emission computed tomography (SPECT). Among the potential targets for such methods, benzodiazepine-binding sites in the human brain have been successfully imaged. This binding site, referred to as the benzodiazepine "receptor" (BZR), is now known to reside on one of several transmembrane proteins, which together constitute the gamma-aminobutyric acid (GABA)-activated chloride ionophore [1-3]. The GABA receptor-BZR-chloride ionophore complex thus accounts for biochemical [4-6] and physiological [6-8] interactions between a variety of ligands that bind to different domains including $\mathrm{GABA}_{\mathrm{A}}$ receptor, the $\mathrm{BZR}$, a barbiturate-binding site, and the chloride channel. Since GABA is the predominant and most widely distributed inhibitory neurotransmitter in the mammalian brain, measurements of BZR binding may yield important information on synaptic function across a variety of brain regions. In addition to providing a possible marker of neuronal integ- rity, in vivo $B Z R$ measurements may allow distinction of the site(s) of drug action or allow detection of primary alterations in the benzodiazepine-binding site in a variety of neurological and psychiatric disorders.

Prior studies with PET have documented cerebral uptake and distribution of several radioligands with high affinity for the central nervous system BZR. Studies following the administation of $\left[{ }^{11} \mathrm{C}\right]$ flunitrazepam [9], $\left[{ }^{11} \mathrm{C}\right]$ suriclone [10], and $\left[{ }^{11} \mathrm{C}\right] \mathrm{RO} 15-1788$ (flumazenil [FMZ]) [11-13] demonstrated brain uptake and evidence of receptor-mediated retention in the brain. Of the available agents, we have focused our attention on FMZ for a variety of reasons. First, it appears to have a high relative proportion of "specific" (i.e., receptor-mediated) retention in the brain [11-14]. Second, it is an antagonist of the BZR $[15,16]$ and is devoid of significant physiological or pharmacological effects in normal individuals [17]. Additionally, as an antagonist in in vitro assays, it demonstrates no alteration in its binding on the basis of endogenous or added GABA or barbiturates $[6,16]$. Finally, the binding of FMZ is specific for the central BZRs (the $\omega_{1}$ and $\omega_{2}$ subtypes) without significant affinity for the pe-
From the *Division of Nuclear Medicine (Department of Internal Medicine) and the + Mental Health Research Institute, Universicy of Michigan, Ann Arbor, MI, and $¥$ Max-Planck-Institut für Neurologische Forschung, Köin, Federal Republic of Germany.
Received Jan 28, 1991, and in revised form Apr 26. Accepted for publication Apr 29, 1991.

Address correspondence to Dr Frey, Division of Nuclear Medicine, B1 G412 University Hospital, 1500 E. Medical Center Drive, Ann Arbor, MI 48109-0028. 
ripheral BZR (the $\omega_{3}$ subtype) $[16,18]$. Thus, its specific in vivo binding should reflect local tissue centraltype BZR availability.

The use of $\left[{ }^{11} \mathrm{C}\right] \mathrm{FMZ}$ for imaging of BZR in human brain was initially reported by Persson and colleagues [11], and has been confirmed in several subsequent investigations $[12-14,19,20]$. In general, the approach to interpretation of these studies has centered on the observation that the amounts and regional patterns of cerebral tracer retention are substantially altered by prior administration of competing benzodiazepines or by reducing the specific activity of the injected radiotracer. A formulation for analysis of $\left[{ }^{11} \mathrm{C}\right] \mathrm{FMZ}$ distribution based on the assumption of pseudoequilibrium between blood and brain was presented previously [14]. In our laboratory, we investigated the kinetics of cerebral $\left[{ }^{11} \mathrm{C}\right] \mathrm{FMZ}$ uptake and retention, and analyzed the results on the basis of formal compartmental modeling [21]. In the present report, we describe the general imaging methods employed in our laboratory for $\left[{ }^{11} \mathrm{C}\right] \mathrm{FMZ}$ studies. In addition, a novel analysis on the basis of a simplified compartmental model is presented. This approach yields graphic pixel-by-pixel depictions of two parameters related to FMZ kinetics: the blood-to-brain transport rate constant and the brain tracer distribution volume (DV) relative to arterial plasma. The latter parameter is shown to be a precise measure and is proportional to local BZR availability as reported in in vitro studies.

\section{Materials and Methods}

\section{Synthesis of $\left({ }^{11} \mathrm{C}\right)$ Flumazenil}

Carbon1 1-labeled FMZ ([N-methyl- $\left.{ }^{11} \mathrm{C}\right] \mathrm{FMZ}$ ) was prepared by a modification [22] of the method of Mazière and associates [23]. Specific activities at the time of injection ranged from 300 to $1,000 \mathrm{Ci} / \mathrm{mmol}$.

\section{Flumazenil Metabolite Chromatograpby}

A procedure for rapid chromatographic separation of authentic FMZ from labeled metabolites in arterial blood was developed by analogy to a prior method used in the analysis of $\left[{ }^{11} \mathrm{C}\right]$ scopolamine distribution [24]. It urilizes the rapid separation achievable by column chromatography, combined with stringent solvent elution conditions and correction for recovery on the basis of a tritiated internal standard.

In order to characterize the chromatographic behaviors of FMZ and its major radiolabeled metabolites, [N-methyl${ }^{3} \mathrm{H}$ ]FMZ (New England Nuclear, Boston, MA) was administered intravenously to a 200-g male Sprague-Dawley rat. Approximately 15 minutes after injection, the animal was killed and samples of arterial blood and plasma, liver, and brain were collected. The solid tissues were homogenized in 4 vol of $95 \%$ ethanol, while aliquots of plasma underwent deproteinization by addition of $1 \mathrm{vol}$ of ethanol. The ethanolic suspensions were centrifuged to pellet the precipitates for 1 minute in a microcentrifuge. Aliquots of the supernatants and of the original whole blood and plasma samples were assayed for radioactivity with the use of liquid scintillation spectroscopy both before and after drying at 60 to $70^{\circ} \mathrm{C}$ Additional aliquots of the ethanolic supernatants were concentrated under vacuum and then chromatographed on silica thin-layer chromatography (TLC) plates (No. 5721, E. Merck, Darmstadt, Federal Republic of Germany) in each of two solvent systems: (1) hexane-benzene-dioxaneammonium hydroxide, 70:50:45:0.5; and (2) dichloromethane-methanol, 9:1. Following development and drying, the plates were sprayed with a fluorographic enhancer (En${ }^{3}$ hance, New England Nuclear, Boston, MA) and apposed to $\mathrm{x}$-ray film for 7 to 14 days at $-70^{\circ} \mathrm{C}$. The resulting autoradiograms were used to locate and recover major labeled metabolites from the plates.

Column chromatographic separation of $\left[{ }^{3} \mathrm{H}\right] \mathrm{FMZ}$ from two major labeled metabolites was investigated with the use of Sep-Pak $C_{18}$ cartridges (Waters, Milford, MA). The columns were prewashed with $0.1 \mathrm{ml}$ of triethylamine followed by $10 \mathrm{ml}$ of methanol and $10 \mathrm{ml}$ of phosphate-buffered saline solution (PBS): sodium chloride (NaCl) $137 \mathrm{mM}$; potassium chloride (KCl) $3 \mathrm{mM}$; sodium phosphate $\left(\mathrm{Na}_{2} \mathrm{HPO}_{4}\right) 8 \mathrm{mM}$; potassium phosphate $\left(\mathrm{KH}_{2} \mathrm{PO}_{4}\right) 1.5 \mathrm{mM} ; \mathrm{pH} 7.4$. Samples of authentic $\left[{ }^{3} \mathrm{H}\right] \mathrm{FMZ}$ or labeled metabolite fractions were added in 1-ml volumes of PBS. Columns were then washed with mobile phases of varying methanol-PBS content. Eluted fractions were collected and assayed by liquid scintillation spectroscopy.

\section{PET Data Acquisition}

Six young volunteers were recruited by advertisement for participation in the study. They were free of significant current illness by history, had normal findings on general physical and neurological examinations, were not taking prescription or over-the-counter medications with central nervous system actions, were nonsmokers, and did not consume excessive amounts of alcohol or caffeine. Informed consent was obtained prior to all studies, and the procedures were approved by the local institutional review boards governing the use of radionuclides and human subjects in research.

The PET imaging was performed with a CTI/Siemens 931/08-12 scanner (Siemens Gammasonics, Inc, Hoffman Estates, IL) in the stationary acquisition mode. The tomograph has a reconstructed spatial resolution of 6- to $7-\mathrm{mm}$ full widch at half maximum (FWHM) within planes and 7- to 8-mm FWHM in the axial direction. Data from eight rings are simultaneously acquired, permitting reconstruction of 15 planes, each separated by $6.75 \mathrm{~mm}$.

Following establishment of percutaneous radial artery and venous access, subjects were positioned supine, with the eyes and ears unoccluded. The scanned field of view encompassed approximately $100 \mathrm{~mm}$, beginning inferiorly at $1.0 \mathrm{~cm}$ above the orbitomeatal line. Five radioactive fiduciary markers, 1 to $2 \mathrm{~mm}$ in diameter, each labeled with approximately $8 \mu \mathrm{Ci}$ of ${ }^{11} \mathrm{C}$, were affixed to the scalp within the field of view. A dynamic series of PET scans was initiated following bolus intravenous injection of 30 to $50 \mathrm{mCi}$ of $\left[{ }^{11} \mathrm{C}\right] \mathrm{FMZ}$, containing less than $30 \mu \mathrm{g}$ of ligand. Scans were acquired over the following 90 minutes according to the following protocol: $4 \times 30$ seconds; $3 \times 1$ minute; $2 \times 2.5$ minutes; $2 \times 5$ minutes; and $7 \times 10$ minutes.

Timed arterial blood samples were withdrawn into heparinized syringes every 10 seconds for the first 2 minutes, 
followed by additional discrete samples at progressively longer intervals throughout the remainder of the scanning session. Following centrifugation, plasma aliquots were assayed for total radioactivity with the use of a sodium iodide well-counter. Additional aliquots were processed by column chromatography at $1,2,3,4,5,7.5,10,15,20,30,45,60$, and 90 minutes to quantify the unmetabolized $\left[{ }^{11} \mathrm{C}\right] \mathrm{FMZ}$ fraction. These latter plasma samples of $0.4 \mathrm{ml}$ were added to tubes containing $0.6 \mathrm{ml}$ of PBS, which additionally contained approximately $0.05 \mu \mathrm{Ci}$ of $\left[{ }^{3} \mathrm{H}\right] \mathrm{FMZ}$ to act as an internal standard for recovery. Following application to the Sep-Pak column, samples were washed with $9 \mathrm{ml}$ of PBS-methanol, 65:35. The unmetabolized fraction was then eluted from the column with $5 \mathrm{ml}$ of methanol. The wash and FMZ fractions thus obtained were assayed for ${ }^{11} \mathrm{C}$ activity in the wellcounter. Aliquots were taken for assay of ${ }^{3} \mathrm{H}$ by liquid scintillation spectroscopy following decay of ${ }^{11} \mathrm{C}$. The unmetabolized fraction of $\left[{ }^{11} \mathrm{C}\right] \mathrm{FMZ}$ in the original plasma sample was then calculated as described elsewhere [24]. Total arterial plasma $\left[{ }^{11} \mathrm{C}\right\} \mathrm{FMZ}$ was used as the input function for compartmental analysis, since prior work demonstrated only slight plasma protein binding [25].

The emission scans were reconstructed and realigned to a common spatial orientation on the basis of the scalp fiduciaries. The images were corrected for attenuation by calculation with the use of an ellipse, and were scaled to account for the differing scan acquisition times and for ${ }^{11} \mathrm{C}$ decay.

Prior receptor radioligand biodistribution experiments from our laboratory have been analyzed with the use of a compartmental model that distinguishes free, nonspecifically bound, and specifically bound tracer in tissue (Fig 1) [26]. Detailed analysis of the kinetic behavior of $\left[{ }^{11} \mathrm{C}\right] \mathrm{FM} Z$ in human brain indicates that the tissue tracer pools are in rapid exchange, allowing simplification to a single tissue compartment representing the combined tracer pools [21]. In this case, the mathematical description of regional brain activity $\mathrm{C}_{\mathrm{T}}$ versus time $t$ is given by:

$C_{\mathrm{T}}(t)=a e^{-b(t)} \otimes C_{\mathrm{p}}(t)$

where

$\mathrm{a}=\mathrm{K}_{1}=f\left(1-\mathrm{e}^{-\mathrm{PS} / f)}\right.$

$\mathrm{b}=\mathrm{k}_{2} /\left(1+\mathrm{k}_{5} / \mathrm{k}_{6}+\mathrm{k}_{3} / \mathrm{k}_{4}\right)$,

and where $C_{\mathrm{p}}(t)$ is the tracer activity in arterial plasma; $\otimes$ denotes the operation of convolution; $f$ represents local cerebral blood flow; PS represents the capillary permeabilitysurface area product; and rate constants $a, b$, and $K_{1}$ through $\mathrm{k}_{6}$ are as defined in the legend to Figure 1. The PET data, omitting the first 30 seconds to minimize effects of intravascular activity, were fit to the relationship in Equation 1 on a pixel-by-pixel basis with the use of the metabolite-corrected arterial input curve and a weighted integral lookup table approach $[27,28]$. This allows calculation and display of two parametric maps, one reflecting ligand transport from blood to brain $\left(\mathrm{K}_{1}\right)$, the second depicting the local ligand $\mathrm{DV}$. The DV is related to the model parameters and to regional receptor availability as follows:

$\mathrm{DV}=\mathrm{a} / \mathrm{b}=\mathrm{K}_{1}\left(1+\mathrm{k}_{5} / \mathrm{k}_{6}+\mathrm{k}_{3} / \mathrm{k}_{4}\right) / \mathrm{k}_{2}$,

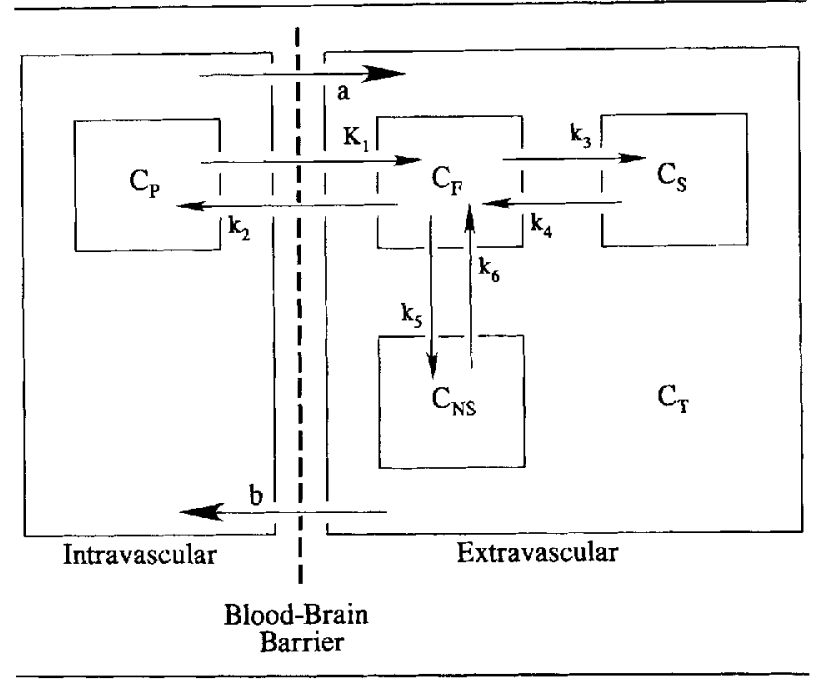

Fig 1. Model describing $\left({ }^{11} \mathrm{C}\right)$ flumazenil distribution in brain as determined by PET. The inner compartments represent the greatest complexity of ligand environments considered, including ligand in arterial plasma $\left(\mathrm{C}_{\mathrm{p}}\right)$ as well as free $\left(\mathrm{C}_{\mathrm{F}}\right)$, nonspecifically bound $\left(\mathrm{C}_{\mathrm{NS}}\right)$, and specifically bound $\left(\mathrm{C}_{\mathrm{S}}\right)$ pools in the brain. Kinetic rate constants $K_{1}$ and $k_{2}$ describe exchange between the arterial plasma and free tissue pools, constants $k_{5}$ and $k_{6}$ relate nonspecific binding to free ligand in tissue, and consiants $k_{3}$ and $k_{4}$ describe specific receptor binding of ligand and its dissociation, respectively. The outer two compartments demonstrate the relationships of these ligand pools to the simplified model employed in the present study. The combined astivity in tissue pools is represented by $C_{T}$, and the parameters $a$ and $b$ describe the transport from plasma to brain and net loss of tracer from brain to plasma, respectively.

where

$\mathrm{k}_{3}=\mathrm{k}_{u n} \mathbf{R}$

$\mathrm{k}_{4}=\mathrm{k}_{\text {off }}$,

and thus,

$\mathrm{k}_{3} / \mathrm{k}_{4}=\mathrm{R} / \mathrm{K}_{\mathrm{D}}$

where $k_{o n}$ and $k_{o f f}$ are the kinetic rate constants for ligand receptor binding and dissociation, $\mathrm{R}$ is the available receptor concentration, and $\mathrm{K}_{\mathrm{D}}$ is the equilibrium binding affinity constant. In the case of a ligand with relatively high affinity for receptor-binding sites (low $\mathrm{K}_{\mathrm{D}}$ ), and when there are large concentrations of receptors available for binding, the DV is dominated by $\mathrm{k}_{3} / \mathrm{k}_{4}$ and is proportional to $\mathrm{R}$.

Following calculation of parametric images of $\mathrm{K}_{1}$ and $\mathrm{DV}$, whole-brain and selected region-of-interest analyses were performed. Regions were identified according to the $\mathbf{K}_{1}$ images, as these afforded good brain structural delineation, even in regions with relatively low $B Z R$ binding. The regions were then mapped onto the corresponding tissue activity and parametric DV images. Average brain parameter estimates were accomplished by calculation of the weighted mean of all 15 whole-slice regions. Whole-brain uptake was then estimated 


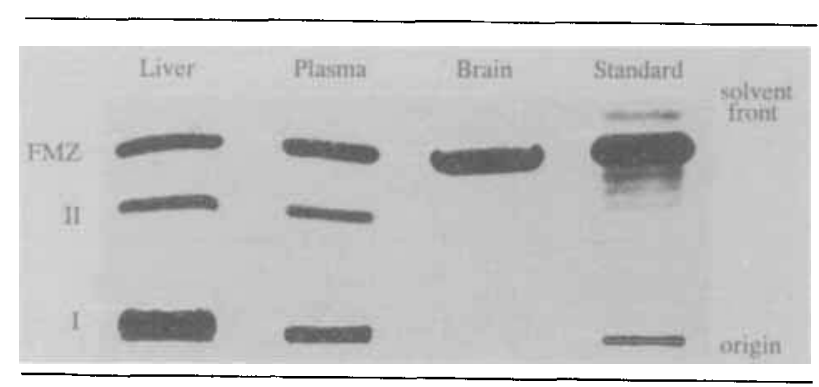

Fig 2. Thin-layer cbromatography of labeled fumazenil (FMZ) and metabolites. An autoradiograph is shown of the chromatographic separation of activity extracted from the liver, plasma, and brain following in vivo injection, using the metbylene chloride-methanol solvent system described in the text. In addition to FMZ, two groups of labeled metabolites are identified in the liver and plasma, designated bands $I$ and II. Note that there is no detectable nonvolatile activity in the brain otber than that associated with FMZ. The quantitatively minor bands present in the $\left(^{3} \mathrm{H}\right) F M Z$ standard lane reflect impurities accounting for less than $3 \%$ of the total activity.

by assumption of a brain volume of $1,237 \mathrm{ml}$ for normal young adults [29].

\section{Results}

Metabolic Fate of $\left.f^{3} H\right\}$ Flumazenil in the Rat

Following systemic injection, $\left[{ }^{3} \mathrm{H}\right] \mathrm{FMZ}$ is rapidly metabolized. Comparison of total and nonvolatile activities revealed the presence of significant amounts of volatile metabolites, which account for over $95 \%$ of the activity in plasma and for 15 to $20 \%$ of the activity in brain and liver at 15 minutes after injection. Chromatographic analysis of nonvolatile activity (Fig 2) revealed the presence of two classes of labeled polar metabolites, one remaining at the origin (band I) and a second (band II) migrating with an $R_{f}$ approximately two thirds that of authentic FMZ. Unchanged FMZ accounted for over $99 \%$ of nonvolatile brain activity, but only $32 \%$ and $14 \%$ of that recovered from plasma and liver, respectively. In plasma, $63 \%$ of the nonvolatile activity was in band $I$ and $6 \%$ was attributable to band II.

\section{Rapid Column Cbromatograpby of Flumazenil in Plasma}

Samples of both ${ }^{3}$ H-labeled metabolites and of $\left[{ }^{3} \mathrm{H}\right] F M Z$ were applied to Sep-Pak columns and eluted with mobile phases containing PBS and between 0 and $45 \%$ methanol. The best differential retention of FMZ versus the metabolites was achieved with use of $35 \%$ methanol. In this case, washing of the column with 8 $\mathrm{ml}$ removed over $98 \%$ of the band I and $91 \%$ of the band II metabolite activities, while retaining $50 \%$ of the FMZ applied (Fig 3). In the subsequent processing of arterial samples from human studies, a 9-ml wash volume was adopted to further ensure high purity of the FMZ fraction.

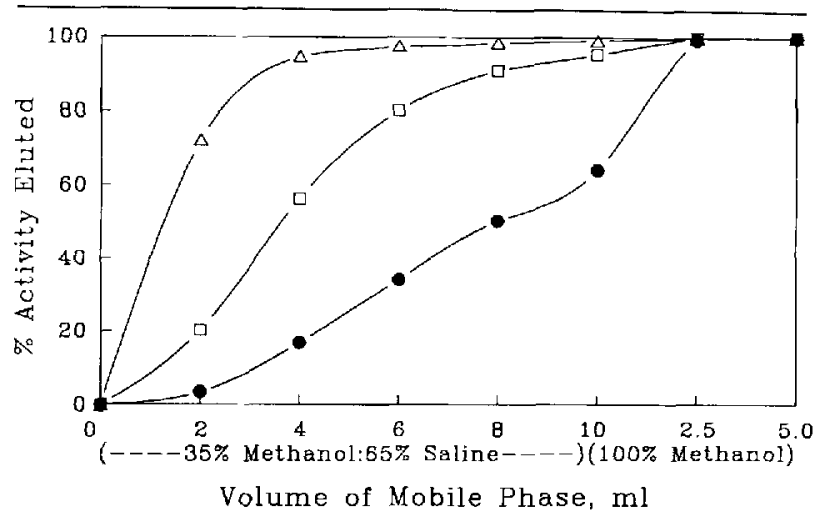

Fig 3. Column cbromatography of labeled flumazenil (FMZ) and metabolites prepared from rat liver. Representative elutions of $\left({ }^{3} \mathrm{H}\right) \mathrm{FMZ}$ (closed circles) and two groups of labeled polar metabolites, designated bands I (open triangles) and II (open squares), from Sep-Pak $C_{18}$ columns initially with five 2-ml volumes of $35 \%$ methanol-65\% PBS, and then followed by two 2.5-ml volumes of $100 \%$ methanol, are sbown.

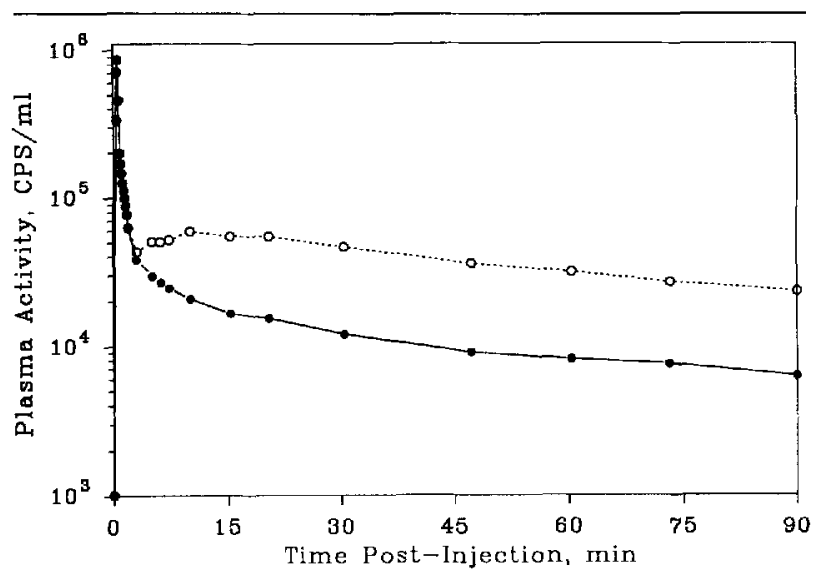

Fig 4. Time course of activity in arterial plasma following a bolus intravenous injection of $\left({ }^{11} \mathrm{C}\right)$ flumazenil in a representative normal buman volunteer (Subject 2, Table 1). Both total (open circles) and metabolite-corrected flumazenil (closed circles) activities are corrected for physical decay of ${ }^{11} \mathrm{C}$. Note the rapid appearance and increase with time in activity associated with labeled metabolites, as indicated by the difference between the curves.

In arterial plasma samples collected following injection in humans, authentic $\left[{ }^{11} \mathrm{C}\right] \mathrm{FMZ}$ cleared rapidly from the circulation (Fig 4). The presence of labeled metabolites was detectable within 2 to 3 minutes, and increased with time to account for approximately $75 \%$ of the activity by 90 minutes after injection.

\section{Uptake and Distribution of $\left({ }^{11} \mathrm{C}\right)$ Flumazenil in Human Brain}

FMZ entered the brain readily, reaching peak levels in whole brain between 5 and 15 mintues after injection. 


\begin{tabular}{|c|c|c|c|c|c|}
\hline \multirow[b]{2}{*}{ Subject } & \multirow[b]{2}{*}{ Age $(y r) / S e x$} & \multicolumn{2}{|c|}{ Flumazenil Dose } & \multirow[b]{2}{*}{$\begin{array}{l}\text { \% Brain } \\
\text { Uptake }^{2}\end{array}$} & \multirow{2}{*}{$\begin{array}{l}\text { Average Brain } \\
\text { Concentration } \\
\text { (nM) }\end{array}$} \\
\hline & & $\begin{array}{l}\text { Activity } \\
\text { (mCi) }\end{array}$ & $\begin{array}{l}\text { Mass } \\
(\mu \mathrm{g})\end{array}$ & & \\
\hline 1 & $19 / \mathrm{M}$ & 33 & 29 & 5.9 & 5.1 \\
\hline 2 & $19 / \mathrm{M}$ & 42 & 12 & 7.1 & 2.5 \\
\hline 3 & $31 / \mathrm{M}$ & 48 & 14 & 4.5 & 1.9 \\
\hline 4 & $19 / \mathbf{F}$ & 41 & 29 & 12.0 & 10.4 \\
\hline 5 & $19 / \mathbf{F}$ & 46 & 19 & 8.4 & 4.8 \\
\hline 6 & $25 / F$ & 50 & 19 & 7.9 & 4.5 \\
\hline
\end{tabular}

${ }^{2} \mathrm{Calculated}$ on the basis of the injected activity and the weighted average of $\left[{ }^{11} \mathrm{C}\right]$ flumazenil activity within all scanned slices between 5 and 7.5 minutes after injection, assuming a whole-brain volume of $1,237 \mathrm{ml}$.

${ }^{b}$ Calculated from the weighted average of $\left[{ }^{11} \mathrm{C}\right\}$ flumazenil activity within all scanned slices between 5 and 7.5 minutes after injection and the specific activity of the injected tracer.

The whole-brain uptake of $\left[{ }^{11} \mathrm{C}\right] \mathrm{FMZ}$ between 5 and 7.5 minutes after injection was $9.3 \pm 3.5 \%$ (mean \pm standard deviation) of the injected dose, resulting in an average brain concentration of $6 \pm 4 \mathrm{nM}$ (Table 1). Analysis of regional time-activity curves indicated rapid ligand uptake across a wide variety of gray matter structures with differential retention according to the anticipated regional BZR density (Fig 5). Thus, activity cleared most slowly from the cerebral cortex; at an intermediate rate from the basal ganglia, thalamus, and cerebellar cortex; and most rapidly from the pons.

\section{Simplified Compartmental Analysis of Regional $\left({ }^{11} \mathrm{C}\right)$ Flumazenil Distribution}

Parametric images of FMZ transport (Fig 6) qualitatively resembled maps of cerebral blood flow. They revealed a relatively homogeneous pattern across major gray matter structures, with considerably lower values observed in white matter, resulting in excellent brain structural definition in the images. By comparison, the DV images revealed large differences across gray matter structures, correlating with known variations in in vitro BZR concentration $[30,31]$. Thus, DV was highest in the cerebral cortex, with progressively lower values observed in the thalamus, cerebellar cortex, caudate, and pons. Images of regional ligand concentration between 15 and 20 minutes after injection, as the distribution increasingly reflects specific binding and may approach a pseudoequilibrium between free and bound ligand, were qualitatively similar to the parametric images of DV.

Region-of-interest analysis (Table 2) of the two parametric images and of the delayed 15- to 20-minute ligand concentration confirmed the previous observations from visual inspection of the images. Regional gray matter $\mathrm{K}_{1}$ values ranged from 0.23 to $0.35 \mathrm{ml}$ plasma $/ \mathrm{ml} \mathrm{brain} / \mathrm{min}$ with coefficients of variation (COV) between 10 and $15 \%$ of the mean values. Average regional ligand DVs ranged from 1.0 to $5.4 \mathrm{ml}$

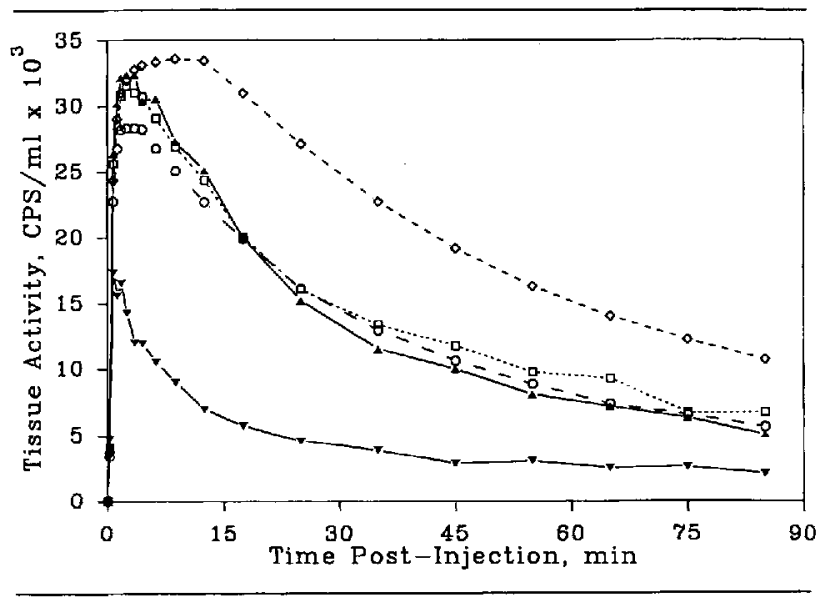

Fig 5. Time course of regional brain activity following a bolus intravenous injection of $\left({ }^{11} \mathrm{Clflumazenil}\right.$ in a representative normal buman volunteer (Subject 2, Table 1). All measurements are corrected for physical decay of ${ }^{11} \mathrm{C}$. Note the similarly rapid extraction followed by differential retention in frontal cortex (open diamonds), thalamus (closed triangles), putamen (open squares), cerebellum (open circles), and the pons (closed inverted triangles).

plasma/ml brain in the pons and the occipital cortex, respectively, with COVs between 10 and $14 \%$. Further improvement in precision was achieved in most regions by representing the parameters as regional ratios to the whole-brain average for each study. In this case, COVs for $K_{1}$ and for DV ranged between 2 and $11 \%$, with the exception of the pons, where no significant improvement was noted.

\section{Discussion}

The present study confirmed and extended prior findings indicating the utility of radiolabeled FMZ in the in vivo measurement of central BZR availability. In agreement with studies on the metabolism of pharmacological doses of FMZ $[25,32]$ and of tracer doses of $\left[{ }^{11} \mathrm{C}\right] \mathrm{FMZ}[33]$, we found evidence in borh the rat and 


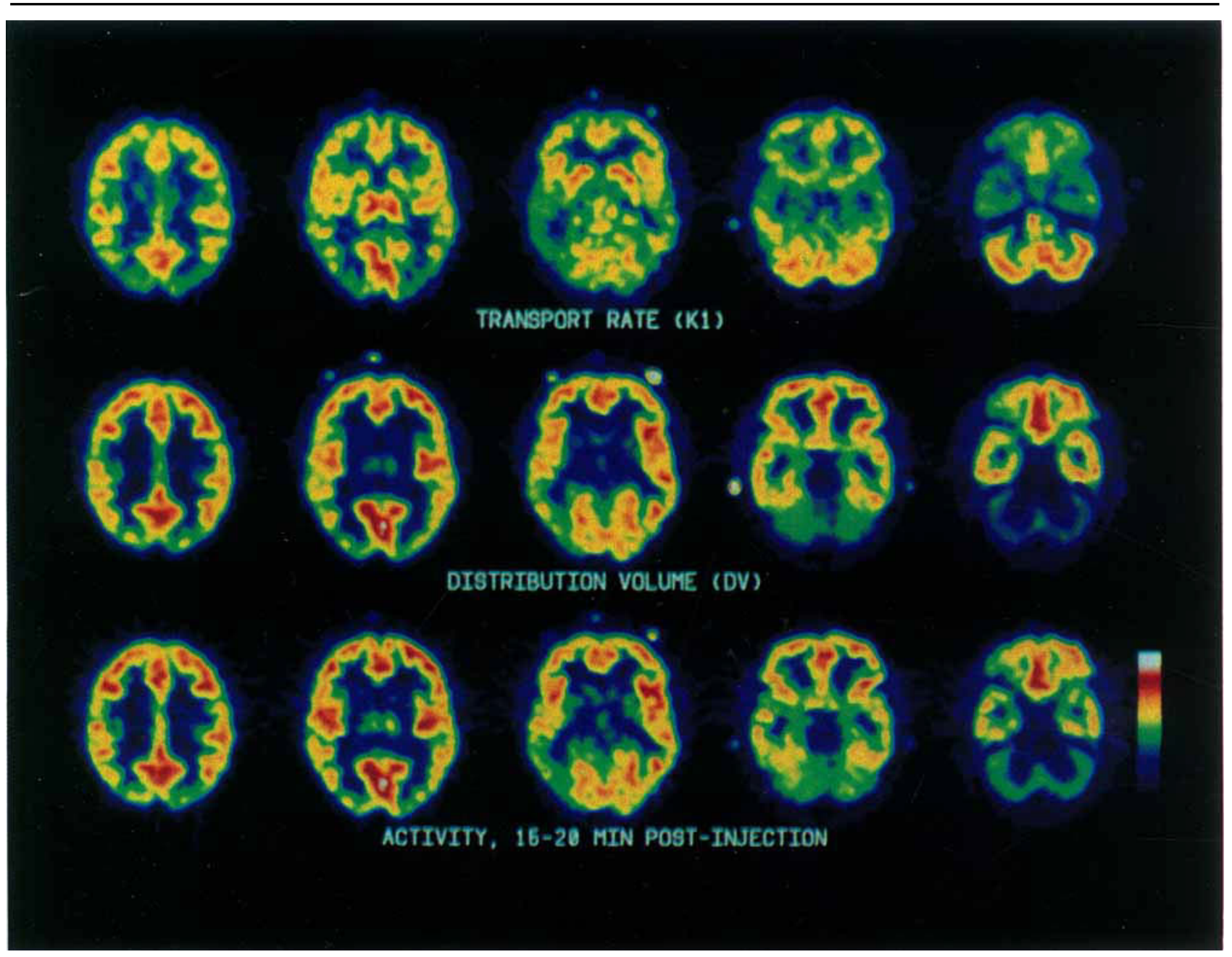

Fig 6. Parametric images of $\left.f^{11} C\right)$ flumazenil transport and distribution volume, and delayed tissue activity in a representative normal volunteer. Images represent five matching transaxial levels selected from sets of 15 simultaneously scanned planes. Note similar ligand transport across gray matter structures. compared with substantially lower values in the white matter (top row). The ligand distribution volume images (middle row) demonstrate distinction between areas of bighest benzodiazepine receptor numbers within the cerebral cortex and regions of fewer benzodiazepine receptors, including the thalamus (level 2), basal ganglia (levels 2 and 3), cerebellar cortex (level 5), and the pons (level 5). Images of $\left(^{11}\right.$ C)fumazenil activity between 15 and 20 minutes after injection (bottom row) resemble the distribution volume maps; bowever, they demonstrate relatively greater activity in the thalamus and cerebellum. All images are pseudocolor maps depicting the displayed variable from bighest (white) to lonest (violet) values according to the color scale at the lower right. 


\begin{tabular}{|c|c|c|c|c|c|c|}
\hline \multirow{2}{*}{$\begin{array}{l}\text { Brain } \\
\text { Region }\end{array}$} & \multirow[b]{2}{*}{$\mathrm{K}_{1}^{\mathrm{b}}$} & \multirow[b]{2}{*}{$\mathrm{DV}^{\mathrm{c}}$} & \multirow[b]{2}{*}{ Activity $^{\mathrm{d}}$} & \multicolumn{3}{|c|}{ Relative to Whole Brain } \\
\hline & & & & $\mathrm{K}_{\mathrm{l}}$ & DV & Activity \\
\hline Occipital cortex & $0.30 \pm 0.04$ & $5.4 \pm 0.7$ & $0.081 \pm 0.029$ & $1.17 \pm 0.10$ & $1.32 \pm 0.07$ & $1.30 \pm 0.07$ \\
\hline Frontal cortex & $0.29 \pm 0.03$ & $4.8 \pm 0.5$ & $0.073 \pm 0.024$ & $1.13 \pm 0.02$ & $1.17 \pm 0.04$ & $1.18 \pm 0.04$ \\
\hline Caudate & $0.31 \pm 0.04$ & $2.3 \pm 0.2$ & $0.037 \pm 0.013$ & $1.20 \pm 0.07$ & $0.56 \pm 0.05$ & $0.61 \pm 0.04$ \\
\hline Putamen & $0.32 \pm 0.05$ & $3.0 \pm 0.4$ & $0.049 \pm 0.015$ & $1.26 \pm 0.07$ & $0.75 \pm 0.02$ & $0.79 \pm 0.02$ \\
\hline Thalamus & $0.35 \pm 0.05$ & $2.9 \pm 0.4$ & $0.050 \pm 0.018$ & $1.37 \pm 0.10$ & $0.70 \pm 0.06$ & $0.81 \pm 0.04$ \\
\hline Cerebellum & $0.28 \pm 0.03$ & $2.8 \pm 0.4$ & $0.048 \pm 0.017$ & $1.10 \pm 0.06$ & $0.70 \pm 0.08$ & $0.78 \pm 0.08$ \\
\hline Pons & $0.23 \pm 0.04$ & $1.0 \pm 0.1$ & $0.014 \pm 0.006$ & $0.90 \pm 0.15$ & $0.24 \pm 0.03$ & $0.23 \pm 0.05$ \\
\hline Whole brain & $0.26 \pm 0.03$ & $4.1 \pm 0.5$ & $0.062 \pm 0.021$ & & & \\
\hline
\end{tabular}

a Values represent the mean \pm standard deviation of observations from 6 individuals

'Values are in $\mathrm{ml}$ of arterial plas $\mathrm{ma} / \mathrm{ml}$ of tissue $/ \mathrm{min}$.

'Values are in $\mathrm{ml}$ of arterial plasma/ml of tissue.

${ }^{d}$ Activity between 15 and 20 minutes after injection expressed as $\mu \mathrm{Ci} / \mathrm{ml}$ of brain $/ \mathrm{mCi}$ of injected dose.

eWeighted average of brain from 15 transaxial slices.

$K_{1}=$ transport rate constant; $\mathbf{D V}=$ distribution volume.

the human that FMZ is rapidly metabolized. However, chromatographic analysis of activity extracted from rat brain revealed that detectable levels of nonvolatile FMZ metabolites are excluded by the blood-brain barrier. Both of the radiolabeled FMZs employed in our studies were labeled in the same position (either ${ }^{3} \mathrm{H}$ or ${ }^{11} \mathrm{C}$ in the $\mathrm{N}$-methyl position), allowing extrapolation of the animal data to the human studies regarding the disposition of metabolites retaining the $N$-methyl group. In addition, a prior study following injection of the major ${ }^{11} \mathrm{C}$-labeled FMZ metabolite, an acid FMZ derivative ( $R O 15-3890$ ), revealed directly that there is no appreciable brain uptake in normal humans [34]. Thus, the cerebral time-activity curves obtained in normal human studies may be interpreted as representing authentic $\left[{ }^{11} \mathrm{C}\right] \mathrm{FMZ}$. The finding of significant relative amounts of volatile activity in the rat following injection of $\left[{ }^{3} \mathrm{H}\right] \mathrm{FMZ}$, however, suggests the need for caution in interpretation of total activity levels following its in vivo injection in experimental animals. The volatile activity in this instance is likely to reflect the presence of $\left[{ }^{3} \mathrm{H}\right]$ water, produced during $\mathrm{N}$-demethylation, by ${ }^{3} \mathrm{H}$ exchange, or both. While labeled water would not be produced in the human studies with $\left[{ }^{31} \mathrm{C}\right] \mathrm{FMZ}$, $\left[{ }^{11} \mathrm{C}\right]$ carbon dioxide might theoretically arise via $N$-demethylation and subsequent oxidation of the $\left[{ }^{11} \mathrm{C}\right]$ formaldehyde. Although the cerebral time-activity curves in our human experiments do not suggest the presence of a labeled metabolite that enters the brain and accumulates at later times, as might be expected of $\left[{ }^{11} \mathrm{C}\right]$ carbon dioxide, it would be important to verify directly its absence in future clinical experiments.

We present here a colunm chromatographic method for the rapid metabolite correction of arterial plasma samples in clinical $\left[{ }^{11} \mathrm{C}\right] \mathrm{FMZ}$ imaging studies. The method is capable of handling over 15 to 20 samples from a single FMZ administration within the time constraints imposed by the 20 -minute half-life of ${ }^{11} \mathrm{C}$. Our results underscore the need for chromatographic processing of plasma to obtain the correct tracer input function required in tracer kinetic analysis. Significant metabolism of FMZ was detectable within minutes following intravenous injection, and the fraction of plasma activity attributable to unchanged FMZ fell to less than $30 \%$ within 15 minutes after injection. Future applications of $\left[{ }^{11} \mathrm{C}\right] \mathrm{FMZ}$ in disease states must therefore be conservative in their design and interpretation. In cases of impaired blood-brain barrier function, some or all of the labeled FMZ metabolites might enter the brain, confounding interpretation of the PET data. Thus, parallel PET examinations of blood-brain barrier integrity may be necessary in some instances.

The method of analysis presented here, resulting in parametric images of radioligand transport and of tissue DV, was applied previously in our laboratories to the imaging of muscarinic receptors [35]. An alternative method previously proposed for analysis of in vivo $\left[{ }^{11} \mathrm{C}\right] \mathrm{FMZ}$ binding $[14]$ makes the assumption that at later times following injection of tracer, an equilibrium between free tracer and specifically bound tracer is achieved. In order to rigorously apply this solution, a scan is required at a time when the nonspecific binding is minimal and unchanging and when total activity in the brain region of interest is constant. This may theoretically require scans at different times after injection for individual brain regions, due to local differences in transport and binding. An approximation of these conditions may be found for ligands that bind and dissociate rapidly from specific sites, by scanning late after injection as tracer is cleared from the brain. The similarity in regional patterns of the parametric DV and the 15- to 20-minute static activity images and the sub- 
sequent quahtitdtive regional comparisons from these images support this assumption. However, it has been demonstrated that the delayed tissue activity under these circumstances may actually overestimate regional receptor availability $[36,37]$. This occurs when the relationship between specific binding and the free tissue ligand represents a secular rather than a true equilibrium, due to continuing decline in plasma tracer concentration. Under these conditions, the overestimate of binding is most severe when the rate of blood clearance is greater than clearance from the brain, and should be most evident in regions of fewest receptors. Thus, the pseudoequilibrium scans in the current study indicate greater apparent receptor binding in the thalamus, basal ganglia, and cerebellum (relative to the cerebral cortex) than do the estimates from the DV maps. Nevertheless, the simplicity of the pseudoequilibrium method may ultimately allow more widespread application of receptor imaging, and it is readily adaptable to SPECT imaging of iodonated ligands, where lower tracer activity doses are permissible and longer image acquisition times are necessary.

Our simplified compartmental analysis appears promising for application to BZR measurements in clinical research. It is necessary, however, to validate further the pharmacological and physiological sensitivities and specificities of the procedure in normal volunteers and, perhaps, in patients with selected pathological conditions as well. Many of the potential applications of BZR imaging involve detection of receptor losses in neurodegenerative diseases including Huntington's disease $\{30,38]$, olivopontocerebeliar atrophy [39], and Alzheimer's disease [40] or in the study of focal epilepsy $[41,42]$. In these cases, local cerebral metabolism and perfusion are reduced in discrete areas of brain [43-46], and it may be predicted that ligand transport in receptor imaging studies will be comparably reduced. Thus, it becomes crucial to isolate effects of ligand transport from measurement of receptor binding in the analysis of local cerebral ligand concentration. The simplified two-parameter method presented in the current study may prove invaluable in these settings, permitting simultaneous estimation of transport alterations in addition to receptor measurements. We have subsequently found that a shortened imaging period of 60 minutes following administration of 20 to $25 \mathrm{mCi}$ of $\left[{ }^{11} \mathrm{C}\right] \mathrm{FMZ}$ results in parametric images of high quality. Test-retest experiments performed recently in our laboratory with this method demonstrated that augmentation of cerebral blood flow to the occipital cortex during visual stimulation results in increased FMZ transport, while FMZ binding estimates are unchanged [47].

The initial studies reported here reveal an unexpectedly low variability in both the ligand transport and the DV measures. Within-individual reliability is suggested by the apparent favorable signal-to-noise ratios of the parametric images, since cerebral structure is readily identifiable in both parametric maps. Calculation of the parametric images makes use of all of the information recorded during the scanning session, and in the case of FMZ, results in images that appear favorable by comparison to the statistical quality of single delayed images. The low between-individual coefficients of variation observed suggest that it should be feasible to detect anticipated pathological receptor changes in the conditions listed previously, using modest numbers of patients. Thus, receptor changes of $20 \%$ would be detectable at the $p<0.05$ level with 0.8 power, using experimental groups of 10 subjects. Actually, the precision of the method appears to equal or exceed those of the most frequently employed PET measures of metabolism or blood flow.

A final advantage of the pixel-by-pixel fits to the two-parameter, two-compartment model employed here is in the utility of the images themselves. The pixel-by-pixel depictions of ligand transport and binding from the present method permit visual screening of ligand transport and binding in the entire brain. Unanticipated local changes may thus be detected without the need for time and labor-intensive data analyses needed by more complex tracer compartmental models. The detailed kinetic descriptions of both blood and brain activity collected, however, will permit post hoc application of these more complex analyses when indicated.

In summary, we developed a simplified compartmental model and analysis of $\left[{ }^{11} \mathrm{C}\right] \mathrm{FMZ}$ distribution in the human brain, which results in images of BZR binding. Although the method requires the sampling and processing of arterial blood samples in addition to collection of PET data, it results in precise transport and binding parameter estimates.

This work was supported by grants 3 PO1 NS15655 and S ROl NS24896 from the National Institures of Health.

The authors acknowledge the excellent and extensive support of the members of the PET/Cyclotron Facility, the Nuclear Pharmacy, and the PET Imaging Suite. The efforts of Jill Rothley, Leslie Botti, Vincent McCormick, Annette Betley, Thomas Mangner, and Steven Toorongian are deeply appreciated. We acknowledge the cooperation and support of Hoffmann-LaRoche, Inc, in these studies, and we are also grateful for the excellent secretarial support of Karen Grahl in preparation of this manuscript.

\section{References}

1. Schofield PR, Darlison MG, Fujita $N$, et al. Sequence and func. tional expression of the $\mathrm{GABA}_{\mathrm{A}}$ receptor shows a ligand-gated receptor superfamily. Nature $1987 ; 328: 221-227$

2. Pritchetr DB, Sontheimer H, Shivers BD. Importance of a novel $\mathrm{GABA}_{\mathrm{A}}$ receptor subunit for benzodiazepine pharmacology. Nature 1989;338:582-585

3. Malherbe P, Sigel R, Baur R, et al. Functional characteristics 
and sites of gene expression of the $\alpha_{1}, \beta_{1}, \gamma_{2}$-isoform of the rat GABA A receptor. J Neurosci 1990;10:2330-2337

4. Olsen RW. GABA-benzodiazepine-barbiturate receptor interactions. J Neurochem 1981;37:1-13

5. Skolnick P, Rice KC, Barker JL, Paul SM. Interaction of barbiturates with benzodiazepine receptors in the central nervous system. Brain Res 1982;233:143-156

6. Farb DH, Borden LA, Chan CY, et al. Modulation of neuronal function through benzodiazepine receptors: biochemical and electrophysiological studies of neurons in primary monolayer cell culture. Ann NY Acad Sci 1984;435:1-31

7. Study RE, Barker JL. Diazepam and (-) pentobarbical: Aluctuation analysis reveals different mechanisms for potentiation of GABA responses in cultured central neurons. Proc Natl Acad Sci USA 1981;78:7180-7184

8. Asano $T$, Ogasawara N. Chloride-dependent scimulation of GABA and benzodiazepine receptor binding by pentobarbital. Brain Res 1981;225:212-216

9. Mazière M, Godot JM, Berger $G$, et al. Positron tomography. A new method for in vivo brain studies of benzodiazepine, in animal and in man. In: Cosra E, DiChiara G, Gessa GL, et al, eds. GABA and benzodiazepine receptors. New York: Raven Press, 1981:273-286

10. Frost JJ, Wagner HN, Dannals RF, et al. Imaging benzodiazepine receptors in man with $\left[{ }^{11} \mathrm{C}\right]$ suriclone by positron emission tomography. Eur J Pharmacol 1986;122:381-383

11. Persson A, Ehrin E, Eriksson L, et al. Imaging of $\left[{ }^{11} \mathrm{C}\right.$-labelled RO 15-1788 binding to benzodiazepine receptors in the human brain by positron emission tomography. J Psychiatr Res 1985; 19:609-622

12. Shinotoh $H$, Yamasaki $T$, Inoue $O$, et al. Visualization of specific binding sites of benzodiazepine in human brain. J Nucl Med 1986;27:1593-1599

13. Pappata S, Samson Y, Chavoix C, et al. Regional specific binding of $\left[{ }^{11} \mathrm{C}\right]$ Ro 151788 to central type benzodiazepine receptors in human brain: quantitative evaluation by PET. J Cereb Blood Flow Metab 1988;8:304-313

14. Persson A, Pauli S, Halldin C, et al. Saturation analysis of spccific ${ }^{11} \mathrm{C}$ Ro $15-1788$ binding to the human neocortex using positron emission tomography. Hum Psychopharmacol 1989; $4: 21-31$

15. Hunkeler W, Möhler $\mathrm{H}$, Pieri L, et al. Selective antagonists of benzodiazepines. Nature 1981;290:514-516

16. Möhler H, Richards JG. Agonist and antagonist benzodiazepine receptor interaction in vitro. Nature 1981;294:763-765

17. Darragh A, Lambe R, O'Boyle $C$, et al. Absence of central effects in man of the benzodiazepine antagonist Ro 15-1788. Psychopharmacology (Berlin) 1983;80:192-195

18. Richards JG, Möhler H, Haefely W. Benzodiazepine binding sites: receptors or acceptors? Trends Pharmacol Sci 1982;3: $233-235$

19. Shinotoh H, Iyo M, Yamada T, et al. Detection of benzodiazepine receptor occupancy in the human brain by positron emission tomography. Psychopharmacology (Berlin) 1989;99:202207

20. d'Argy R, Gillberg P-G, Stalnacke C-G, et al. In vivo and in vitro receptor autoradiography of the human brain using an ${ }^{11} \mathrm{C}$ labelled benzodiazepine analogue. Neurosci Lett 1988;85:304310

21. Koeppe RA, Holthoff VA, Frey KA, et al. Compartmental analysis of $\left[^{11} \mathrm{C}\right]$ flumazenil kinetics for the estimation of ligand transport rate and receptor distribution using positron emission tomography. J Cereb Blood Flow Metab 1991;11:735-744

22. Watkins GL, Jewett DM, Mulholland GK, et al. A captive solvent method for rapid $\mathrm{N}-\left[{ }^{11} \mathrm{C}\right]$ methylation of secondary amides: application to the benzodiazepine, 4'-chlorodiazepam (RO54864). Int J Appl Rad Isotopes 1988;39:441-444
23. Mazière M, Hantraye $P$, Prenant $C$, et al. Synthesis of RO 15-1788 et ${ }^{11} \mathrm{C}$ : a specific radioligand for the in vivo study of central benzodiazepine receptors by positron emission tomography. Int J Appl Radiat Isot 1984;35:973-976

24. Frey KA, Koeppe RA, Mulholland GK, et al. In vivo muscarinic cholinergic receptor imaging in human brain with $\left[{ }^{11} \mathrm{C}\right]$ scopolamine and positron emission tomography. J Cereb Blood Flow Metab 1991 (in press)

25. Klotz U, Ziegler G, Reimann IW. Pharmacokinetics of the selective benzodiazepine antagonist Ro $15-1788$ in man. Eur $\mathrm{J}$ Clin Pharmacol 1984;27:115-117

26. Frey KA, Hichwa RD, Ehrenkaufer RLE, Agranoff BW. Quantitative in vivo receptor binding III: tracer kinetic modeling of muscarinic cholinergic receptor binding. Proc Natl Acad Sci USA 1985;82:6711-6715

27. Alpert NM, Eriksson L, Chang JY, et al. Strategy for the measurement of regional cerebral blood flow using short-lived tracers and emission tomography. J Cereb Blood Flow Metab $1984 ; 4: 28-34$

28. Koeppe RA, Hutchins GD, Rothley JM, Hichwa RD. Examination of assumptions for local cerebral blood flow studies in PET. J Nucl Med 1987;28:1695-1703

29. Davis PJM, Wright EA. A new method for measuring cranial cavity volume and its application to the assessment of cerebral arrophy at autopsy. Neuropathol Appl Neurobiol 1977;3:341358

30. Möhler $\mathrm{H}$, Okada T. The benzodiazepine receptor in normal and pathological human brain. Br J Psychiatry 1978;133: 261-268

31. Zezula J, Cortés R, Probst A, Palacios JM. Benzodiazepine receptor sites in the human brain: autoradiographic mapping. Neuroscience 1988;25:771-795

32. Klotz U. Drug interactions and clinical pharmacokinetics of flumazenil. Eur J Anaesthesiol 1988;2:103-108

33. Swahn C-G, Persson A, Pauli S. Metabolism of the benzodiazepine antagonist ${ }^{11} \mathrm{C}$-Ro $15-1788$ after intravenous administration in man. Hum Psychopharmacol 1989;4:297-301

34. Persson A, Pauli S, Swahn CG, et al. Cerebral uptake of ${ }^{11} \mathrm{C}$-Ro 15-1788 and its acid metabolite ${ }^{11} \mathrm{C}-\mathrm{Ro}$ 15-3890; PET study in healthy volunteers. Hum Psychopharmacol 1989;4:215-220

35. Frey KA, Koeppe RA, Mulholland GK, et al. Quantification of regional cerebral muscarinic receptors in human brain with the use of [C-11]tropanyl benzilate and positron emission tomography. J Nuci Med 1990;31:779

36. Gjedde A, Wienhard K, Heiss W-D, et al. Comparative regional analysis of 2-fluorodeoxyglucose and methylglucose uptake in brain of four stroke patients. With special reference to the regional estimation of the lumped constant. J Cereb Blood Flow Metab 1985;5:163-178

37. Carson RE, Blasberg RG, Channing MA, et al. XII-4. Tracer infusion for equilibrium measurements: applications to ${ }^{18} \mathrm{~F}$ cyclofoxy opiate receptor imaging with PET. J Cereb Blood Flow Metab 1989;9:\$203

38. Walker FO, Young AB, Penney JB, et al. Benzodiazepine and GABA receptors in early Huntington's disease. Neurology 1984;34:1237-1240

39. Albin RL, Gilman S. Auroradiographic localization of inhibitory and excitatory amino acid neurotransmitter receptors in human normal and olivopontocerebellar atrophy cerebellar cortex. Brain Res 1990;522:37-45

40. Shimohama S, Taniguchi T, Fujiwara M, Kaneyama M. Changes in benzodiazepine receptors in Alzheimer-type dementia. Ann Neurol 1988;23:404-406

41. Johnson EW, de Lanerolle NC, Kim JH, et al. Autoradiographic quantitation of central and peripheral benzodiazepine receptors in human epileptogenic tissue. Soc Neurosci Abstr 1990;16:308

42. Savic I, Roland P, Sedvall G, et al. In-vivo demonstration of 
reduced benzodiazepine receptor binding in human epileptic foci. Lancet 1988;2:863-866

43. Kuhl DE, Phelps ME, Markham $\mathrm{CH}$, et al. Cerebral metabolism and atrophy in Huntington's disease determined by ${ }^{18}$ FDG and computed tomographic scan. Ann Neurol 1982;12:425-434

44. Gilman S, Markel DS, Koeppe RA, et al. Cerebellar and brainstem hypometabolism in olivopontocerebellar atrophy detected with positron emission tomography. Ann Neurol 1988;23: $223-230$

45. Benson DF, Kuhl DE, Hawkins RA, et al. The fluorodeoxyglu- cose ${ }^{18} \mathbf{F}$ scan in Alzheimer's disease and multi-infarct dementia. Arch Neurol 1983;40:711-714

46. Kuhl DE, Engel J Jr, Phelps ME, Selin C. Epileptic patterns of local cerebral metabolism and perfusion in humans determined by emission computed tomography of ${ }^{18} \mathrm{FDG}$ and ${ }^{13} \mathrm{NH}_{3}$. Ann Neurol 1980;8:348-360

47. Holthoff VA, Koeppe RA, Frey KA, et al. Differentiation of radioligand delivery and binding in the brain: validation of a two-compartment model for $\left[{ }^{\mathbf{l}} \mathrm{C}\right]$ flumazenil. J Cereb Blood Flow Metab 1991;11:745-752 